\title{
THE CONSTITUTIONAL FUNCTION OF THE SENATE IN RESPECT TO APPOINTMENTS
}

\section{ERNEST SCOTT $t$}

The purpose of this article is twofold-first, to discuss the background and decision of the George Otis Smith ${ }^{1}$ case, and secondly, to consider the question of the constitutional function of the Senate in reference to Presidential appointments. This problem was raised by the $S m i t h$ case but not decided by it.

The Federal Power Commission was originally created under an act of Congress passed in $1920 .^{2}$ By the amendment of June $23,1930{ }^{3}$ the Commission was reorganized and became a body of five Commissioners "who shall be appointed by the President by and with the advice and consent of the Senate." In pursuance of his duties under the Constitution ${ }^{4}$ and statute, the President of the United States, on December 3, I930, transmitted to the Senate the nomination of George Otis Smith of Maine, to be a member of the Commission for a term expiring June 22, I935. Thereafter, on December 20, I930, the nomination of Smith came before the Senate sitting in open executive session. After some debate a vote was taken on the question of confirmation or rejection." By a vote of 38 to 22 (35 Senators not voting) the Senate advised and consented to the appointment of Smith to the office for which he had been nominated. Subsequently and on the same day it was ordered by the Senate that all resolutions of confirmation be forwarded forthwith to the President. This special order to notify the President immediately was made in accordance with paragraph 4 of Rule XXXVIII of the Standing Rules of the Senate ${ }^{5}$ which

† A. B., 1925, LL: B., I929, University of Pennsylvania; Associate Editor, UiviversiTY of Pennsylvania Law Review 1928-29; member of the Pennsylvania Bar.

${ }^{1}$ United States v. Smith, 286 U. S. 6, 52 Sup. Ct. 475 (I932).

${ }^{2} 4$ I STAT. IC6́3 (I920), I6 U. S. C. A. \$ 792 et seq. (1927).

${ }^{3} 46$ STAT. 797 (1930), I6 U. S. C. A. § 792 ef seq. (I931).

"United States Constitution, Art. II, sec. 2 provides:" ". . He (the President) shall nominate, and by and with the Advice and Consent of the Senate, shall appoint Ambassadors, other public Ministers and Consuls, Judges of the Supreme Court, and all other cfficers of the United States, whose Appointments are not herein otherwise provided for, and which shall be established by Law; . . . The office of the Federal Power Commissioner is not provided for in the Constitution but is established by law; therefore the above provision of Sec. 2 is applicable. Sec. 3 of the same Article directs that the President "shall Commission all of the Officers of the United States."

- United States v. Smith, supra note I, at 16,52 Sup. Ct. at 477 . The full text of this paragraph reads: "4. Nominations confirmed or rejected by the Senate shall not be returned by the Secretary to the President until the expiration of the time limited for making a motion to reconsider the same, or while a motion to reconsider is pending, unless otherwise crdered by the Senate." 
provided that the Secretary of the Senate shall not notify the President of the confirmation or rejection of a nomination acted upon until the time allowed for reconsideration (two days of actual executive session) shall have expired unless otherwise ordered by the Senate. This blanket notification order was entered late in the evening of Saturday, December 20, just prior to the adjournment of the Senate for the Christmas holidays, and, as to Smith's confirmation, was executed by the Secretary of the Senate on the morning of Monday, December $22 .^{6}$ Later, on the same day, the President signed and, through the Department of State, delivered to Smith a commission purporting to appoint him a member of the Federal Power Commission, and designating him as chairman thereof. Smith then, on the same date, took the oath of office and immediately entered upon the discharge of the duties of Commissioner. On or about the same dates four others were nominated by the President and confirmed by the Senate in order to constitute the full five man commission. Two of these men were commissioned by the President at the same time as Smith, the other two a short time afterward.

One of the first official acts of the new Commission took place on December 23, the day following the induction into office of George Otis Smith. As a result of the first meeting of the new Commission (three members being present, the other two not yet having been sworn into office) a notice was sent to all employees of the former Commission stating that "your services automatically terminated on December 22nd with the going out of existence of the Commission under which you have been employed". In the same notice all employees but three-King, Russell, and Bonnerfound this paragraph:

"In line with the authority contained in the above mentioned act, the Commission will proceed later to appoint such officers and employees as are necessary in the execution of its functions as soon as can be determined what personnel is required. In the meantime the Civil Service Commission has been requested to authorize your temporary employment for not exceeding 30 days."

All notices were signed by Smith as chairman of the new Commission.

William V. King, the Commission's general accountant, Charles F. Russell, the solicitor for the Commission, and Frank E. Bonner, executive

${ }^{\circ}$ United States v. Smith, sitpra note I, at 10, n. I, 52 Sup. Ct. at 476 , n. I. The notice sent to the President by the Senate took the following form:

"In Executive Session. Senate of The UNited States.

Saturday, December 20, 1930.

RESOLVED, That the Senate advise and consent to the appointment of the followingnamed persons to the offices named agreeably to their respective nominations:

Federal Power Commission.

George Otis Smith, to be a member for the term expiring June 22, I935.

Attest:

(Signed) Edwin P. Thayer, Secretary." 
secretary of the old Commission, were thus summarily dismissed and not even temporarily reemployed. Bonner had publicly announced his intention of severing connections with the Commission, but this action on the part of the Commission as to King and Russell aroused a storm of protest from some quarters.

When the Senate reconvened on January 5, I93I, after the Christmas recess, the matter came up for instant and acrimonious discussion. Reference to the Congressional Record for January 5 and 6, I93 ${ }^{\top}{ }^{7}$ will demonstrate that there then existed considerable feeling that this precipitate dismissal of Russell and King indicated that the newly appointed Commissioners were not fitted for office. Those Senators who were dissatisfied with the situation, realizing that the Senate possessed no removal powers, ${ }^{8}$ sought another method to clear the atmosphere. Paragraph 3 of Rule XXXVIII ${ }^{9}$ of the Standing Rules of the Senate provided that a nomination may be reconsidered on the same day on which the vote was taken, or on either of the next two days of actual executive session, provided, that if notice of the confirmation has been sent to the President, the motion to reconsider must be accompanied by a motion to request the President to return such notification.

On January 5, which was the very next day of actual executive session of the Senate after the date of Smith's confirmation by that body, a motion to reconsider the question of Smith's confirmation was duly made by Senator Walsh of Montana, who had voted to confirm, and a motion was also made to request the President to return the resolution of confirmation which had passed into his possession. Both motions were adopted by more than the required majority and the President was notified in due course.

The President, on January Io, I93I, informed the Senate by a message in writing that he had theretofore appointed Smith to the office in question, after receiving formal notice of confirmation, and he therefore refused to accede to the Senate's request. This message was not sent until the President had asked for and received a formal opinion from the Attorney General which recognized the validity of Smith's appointment and denied the right of the Senate to reconsider the transaction. ${ }^{10}$

${ }^{7} 74$ CONG. Rec. I389 et seq. (1931).

${ }^{8}$ Myers v. United States, 272 U. S. 52, 47 Sup. Ct. 21 (1926).

- United States v. Smith, supra note $\mathrm{r}$, at 16,52 Sup. Ct. at 477 . The full text of this paragraph reads: " 3 . When a nomination is confirmed or rejected, any Senator voting in the majority may move for a reconsideration on the same day on which the vote was taken, or on either of the next two days of actual executive session of the Senate; but if a notification of the confirmation or rejection of a nomination sliall have been sent to the President before the expiration of the time within which a motion to reconsider may be made, the motion to reconsider shall be accompanied by a motion to request the President to return such notification to the Senate. Any motion to reconsider the vote on a nomination may be laid on the table without prejudice to the nomination, and shall be a final disposition of such motion."

${ }^{20} 36$ Op. ATT'Y GEN. 382 (193I). 
Thereafter a motion was made and adopted in the Senate directing the Executive Clerk of the Senate to place on the executive calendar for the action of the Senate "The name and nomination of the said George Otis Smith". Subsequently, on February 4, I93I, the President pro tem of the Senate put to the Senate the question of advice and consent to the appointment of Smith and a majority of the Senators present voted in the negative. Notification of this action was sent to the President.

On the following day, February 5, I93r, the Senate by resolution requested the United States Attorney for the District of Columbia to institute in the Supreme Court of the District of Columbia proceedings in quo warranto under the Code of the District to test Smith's right to hold his office. ${ }^{11}$ The District Attorney complied with the request of the Senate and the proceeding was duly instituted on May 4, I93I.

Thus began the litigation in the case of United States of America $\%$. George Otis Smith. Thus it occurred that an attempt at political reprisal threatened to develop into a parliamentary and constitutional controversy between President and Senate relative to the appointive powers of the former, the rule making powers of the latter, and the proper sphere of each.

In the litigation precipitated by the Senate, issue was joined on petition and answer. The lower court sustained Smith and filed an order denying the petition for a writ of quo warranto, supported by a cogent opinion from the hand of Judge Peyton Gordon. ${ }^{12}$ However, an immediate appeal was noted by the Senate to the Court of Appeals of the District of Columbia, which Court without delay certified a question of law to the Supreme Court of the United States. The gist of that question was:

"Is it or is it not within the power of the United States Senate to annul a presidential appointment by rescinding within two days of actual executive session, its advice and consent to a nomination after, by order of the Senate, notice of that advice and consent has been sent to the President, and after the President in reliance thereon has signed the commission of the nominee, and after the President has declined to comply with the request of the Senate for return of the notification?"

Immediately following the certification of the question involved, a motion was made to bring up the entire record and cause for consideration by the Supreme Court of the United States. This motion was duly granted,

In In normal course, the Attorney General would have been requested to institute the custer proceedings. However, since he had advised the President by formal opinion dated 1an. IO, I93I, silpra note Io, that Smith's appointment was valid, he could not well become the acting plaintift in the projected litigation. Thercfore the request was issued to the United States Attorney for the District of Columbia. At the argument before the Supreme Court an able presentation in support of Smith's position was made by the Attorney General appearing anicus curice.

12 Opinion filed December 5, I93I in the cause United States of America, petitioner, v. George Otis Smith, respondent, Supreme Court of the District of Columbia Law No. 79,553. 
resulting in the presentation to the Sipreme Court of all matters made a part of the record in the case at any time by either party or by order of court.

On May 2, I932 (within one year from the date court proceedings were first instituted), the Supreme Court handed down its unanimous decision. Mr. Justice Brandeis wrote the opinion affirming the judgment of the lower court which had dismissed the Senate's petition for Smith's ouster.

Before stating the grounds upon which the opinion was based it seems pertinent to review briefly the arguments upon which the Senate relied before the Supreme Court and so grasp the full significance of the Senate objective. It was advanced that the action of the Senate in assenting to the nomination of Smith on December 20, I930, and ordering that the President be notified, was taken subject to its rules and had only the effect provided for by them; that the rules empowered the Senate, in plain and unambiguous terms, to entertain, at any time prior to the expiration of the next two days of actual executive session, a motion to reconsider its vote advising and consenting to the appointment, although it had previously ordered a copy of the resolution of consent to be forwarded forthwith to the President; that the Senate's action can not be held to be final so long as it retained the right to reconsider; that the Senate did not by its order of notification waive its right to reconsider or intend that the President should forthwith commission. Smith; that the rules did not make the right of reconsideration dependent upon compliance by the President with its request that the resolution of consent be returned; that the rules were binding upon the President and all other persons dealing with the Senate in this matter; that as the President was charged with knowledge of the rules, his signing of the commission prior to the expiration of the period within which the Senate might entertain a motion to reconsider had no conclusive legal effect; and that the nominee who had not been legally confirmed could, not by his own acts in accepting the commission, taking an oath of office and beginning the discharge of his duties vest himself with any legal rights; that a survey of the historical development of the Senate Rules relating to reconsideration confirmed such interpretation of those rules, and finally that that interpretation was further confirmed by the multitudinous instances appearing in the Executive Journal of the Senate in which the President upon Senate request returned resolutions to it.

On the other hand, Smith's counsel argued that, in view of the decision in Marbury v. Madison, ${ }^{13}$ it is settled that where the President has nominated, the Senate has advised and consented, and a commission has been signed by the President, the appointment is complete and the appointee is entitled to office unless and until properly removed; that the only point in the Smith case left open by that decision was whether the Senate may

${ }^{23}$ I Cranch 137 (U. S. I803). 
nullify a presidential appointment by subsequent rcconsideration proceedings, after notification of confirmation has been sent to the President and after the commission has been issued to the appointee in reliance upon that notification; that when the Senate acted, and notified the President of its action by an official message, the legislative branch of the Government necessarily parted with its control over the subject matter which thereupon passed into the hands of the Executive; that this left the Senate without power to reverse its action thereafter unless control of the transaction was restored to it by voluntary action of the President; that a study of the provisions of the Senate Rules and the history of their development, as well as the practice thereunder, lent strength to this interpretation, and that to construe them otherwise would result in interference with the President in the discharge of his constitutional functions, would recognize interlocutory or conditional consent by the Senate and would render the rules invalid and unconstitutional. In short, Smith's position was presented in the alternative. First, that the Senate Rules reasonably interpreted did not empower the Senate to do what it here attempted to do; secondly, if such interpretation as claimed by Senate counsel should be placed on those rules, they must necessarily be unconstitutional.

The Supreme Court upheld Smith's title to office on the first contention relating to the interpretation of Senate rules. This, of course, obviated consideration of the second contention and avoided the necessity of any constitutional discussion. ${ }^{14} \mathrm{Mr}$. Justice Brandeis laid emphasis upon six points in upholding the validity of Smith's title to office.

First he stated that the issue in question primarily related to the construction of the Senate reconsideration rules, not to their constitutionality, and that the wisdom or folly of those rules was not a matter for the court to determine. ${ }^{15}$

Secondly, he was careful to point out that notification of the President concerning the confirmation or rejection of a nomination normally did not go forward under the Senate Rule until two days of actual executive session had passed, unless otherwise ordered by the Senate; that the Senate had otherwise ordered in the instant case-thus making the question turn upon the meaning and effect of this special procedure.

Thirdly, he found the natural meaning of such an order of notification to be that the Senate consents that the appointment be forthwith completed and that the appointee take office, believing that it is essential to the orderly conduct of public business that formality be observed in the relations between different branches of the Government charged with concurrent duties.

${ }^{1 *}$ The constitutionality of a reconsideration rule requiring the construction advanced by the Senate in the Smith case for the present rule would have to be determined under United States Y. Ballin, I44 U. S. I, 12 Sup. Ct. 507 (I89I).

${ }_{15}$ This is in recognition of the rule laid down in United States v. Ballin, supra note 14, dealing with the constitutionality of a rule of the House of Representatives. 
Fourthly, he found nothing in the history of the rules which lent support to the contention of the Senate, and much in their history to the contrary..$^{16}$

Fifthly, the court's construction of the rules was confirmed by an examination of the precedents arising since 1868 when those rules took substantially their present form. ${ }^{17}$

Sixthly, with a touch of restrained humor, attention was called to the fact that reference to the Congressional Record demonstrated that, while the Senate was busy construing its reconsideration rules one way, its counsel was busy urging an exactly opposite interpretation upon the Supreme Court. ${ }^{15}$ In the words of Mr. Justice Brandeis "to place upon the standing rules of the Senate a construction different from that adopted by the Senate itself when the present case was under debate is a serious and delicate exercise of Judicial power. . . . We are confirmed in the view we have taken by the fact that since the attempted reconsideration of Smith's con-

${ }^{20}$ The Supreme Court opinion gives an excellent discussion concerning the history of the Senate Rules relating to reconsideration of nominations. This article could add nothing to it.

${ }^{27}$ Some discussion of the historical precedents will be found in the text of this article. This matter is also given full consideration in the Supreme Court opinion.

${ }^{28}$ In the 74 CoNG. REC. $6489-6490$ (I93I) will be found the following example of the proceedings referred to:

The Chief Clerk read the nomination of Louie W. Strum to be United States district judge, southern district of Florida (additional position).

The President pro tempore. Without objection, the nomination is confirmed.

Mr. Fletcher. Mr. President, this judge is very much needed, and has been for some months. He is approved by both Senators from Florida, and was unanimously approved by the subcommittee of the Committee on the Judiciary and by the full Committee on the Judiciary. There is no opposition on record. I ask unanimous consent to waive the rule about two subsequent executive sessions, and that the President be notified with regard to this action.

The President pro tempore. Is there objection to the request of the Senator from Florida that the President be notified of the action taken in the confirmation of Judge Strum? The Chair hears none, and the President will be notified."

An amusing instance occurred in relation to the confirmation of Ogden L. Miills and Arthur A. Ballantine. On Feb. Io, 1932, when Messrs. Mills and Ballantine were confirmed, objection was made to the immediate notification of the President. 75 CoNG. Rec. 3782 (1932), but on Feb. II, I932, 75 CoNG. RFC. 388I (1932), the following proceedings took place:

"Notification of the President.

Mr. Smoot. Mr. President, on yesterday I asked unanimous consent that the President be notified of the advice and consent of the Senate to the nominations of Ogden L. Mills to be Secretary of the Treasury and Arthur A. Ballantine to be Under Secretary of the Treasury. At the time the Senator from Nebraska (Mr. Norris) objected. I have been promised by him that if I would bring up the matter today he would have no further objection to the request. I therefore renew my request that the President be notified of the advice and consent of the Senate to the nominations referred to.

The Vice President. Is there objection?

Mr. Norris. Mr. President, the Senator from Utah came to see me today about my objection made on yesterday. I understand it is desirable that these gentlemen be installed in their respective offices in order that there may be no interference with a prearranged high-class social function. Of course, I do not want to interfere with anything of that nature, so I withdraw my objection.

The Vice President. Without objection, the President will be notified that the Senate advises and consents to the nominations."

Similar proceedings can be found by reference to the following citations: 75 Cong. REc., I003, II3I (193I); Id., 3071, 3415, 3582, 4724 (1932). 
firmation, the Senate itself seems uniformly to have treated the ordering of immediate notification to the President as tantamount to authorizing him to proceed to perfect the appointment." 19

The opinion is sound, logical, and compelling. It squarely decides the issue on the facts presented. However, it will be remembered that in final analysis the question decided concerned only the meaning and effect to be attributed to the special order of notification sent by the Senate to the President when executive action had been taken in reliance thereon. Although illuminated by historical interest, and although in this instance defeating Senate encroachment upon the appointive power of the executive under the guise of reconsideration, the George Otis Smith decision remains based upon fairly narrow grounds. Disappointingly, though quite properly, it fails to settle a constitutional question of considerable magnitude. The Court saw this question but avoided it. To quote Mr. Justice Brandeis : 20

"Nor need we consider whether the President might decline to accede to a request to return the Senate's resolution if he received it before making the appointment."

That question, now to be discussed, and which the Supreme Court declined to decide is: has the Senate, under the existing rules, power to change its mind after notifying the Executive and before a commission has been signed; or, to put the problem another way, at what point does Senate consent become irrevocable; or, stated still differently, could the President issue a valid commission in reliance upon official notification of Senate confirmation where notice of recall reached him before the appointment was perfected?

This problem (which is by no means academic) will be attacked from three angles. ${ }^{21}$ First, an historical approach based on a brief consideration of the mass of data collected by counsel in the Smith case from the Executive Journals of the U. S. Senate, from the records of nominations and appointments kept in the executive offices of the White House, and from the records of government departments where existing. ${ }^{22}$ Secondly, a discussion of such legal precedent as exists, gathered from an analysis of pertinent reported decisions. Thirdly, an attempt will be made to study

${ }^{18}$ United States v. Smith, stipra note I, at 48,52 Sup. Ct. at 483 .

${ }^{20}$ United States v. Smith, supra note I, at 34,52 Sup. Ct. at 478 .

${ }^{21}$ Of course, for the purposes of this discussion, it is assumed that the present Senate Reconsideration Rules remain in effect.

${ }_{22}^{2}$ This material was compiled by counsel in the case with the aid of the Legislative Reference Bureau of the Library of Congress and appears as part of the record in United States v. Smith. 
the practical situation involved and apply to it such apposite fundamental concepts as may be gleaned from historical and legal authority.

Historically, the exact situation has never squarely arisen. No President has stood upon his rights and insisted upon perfecting an appointment in reliance upon an official notification of confirmation where notice of Senate reconsideration and a request for return has reached him before the last act was done to consummate the appointment. But a close approximation of these circumstances occurred in 1868. President Johnson then nominated one Noah L. Jeffries to be Register of the Treasury. ${ }^{23}$ This nomination was confirmed by the Senate. Notification thereof arrived at the White House about II o'clock in the morning of February I4. A commission was at once prepared in the State Department. On the same day Executive signature was obtained thereon and the commission was then forwarded to the Treasury Department for delivery to Jeffries. On the afternoon of February I4, and still within the time permitted by the standing rules, a motion to reconsider was adopted by the Senate together with the appropriate motion to request the President to return the resolution. Notification of these resolutions was delivered to the Executive mansion about 5 P. M. on the fourteenth. It does not appear whether or not the President had signed Jeffries' commission before receipt of the Senate's message of recall. But it does appear that Jeffries received his commission and took the oath of office at the Treasury Department on the morning of the I $5^{\text {th }}$ before the Treasury Department had received the Senate notification delivered to the White House the previous afternoon. Several days later the President returned to the Senate its resolution of confirmation with a report from the Treasury Department stating that Jeffries had been commissioned and taken the oath of office before the request for return had been received by it. This report was referred to a committee consisting of three members of the Senate Judiciary Committee. This Sub-committee considered the matter and advised the Senate that, in the opinion of the Committee, ${ }^{2 t}$ reconsideration might be proceeded with if desired because "before Mr. Jeffries had been qualified or commissioned . . . the President . . . had received notice from the Senate that it had not finally acted upon the question of advising and consenting to the nomination. . . ." No further proceedings were had in the Senate in respect to this nomination. However, Jeffries was nominated as Commissioner of Internal Revenue four months later and rejected by the Senate, ${ }^{25}$ while just a year afterward one John Allison was nominated register "in place of N. L. Jeffries, resigned." 26

${ }^{2}$ I6 SEN. EXEC. J. 3, 166-167, 168, 178, 184, 195-7.

" I6 id. I95-7.

$\approx$ I6 id. 340,370 .

${ }^{25}$ I7 id. 49. 
Except for the opinion of a subcommittee of the Senate to the effect that the Senate has power to proceed to reconsider a nomination where notification of reconsideration has reached the President before action on the previous confirmation, this precedent is of little value to either side of the argument. Four factors rob the case of much importance. (I) The President may have signed Jeffries' commission before receipt of Senate request for return. (2) The Senate dropped the matter and actually never did reconsider the nomination. (3) Jeffries, soon after appointment, resigned from his office either to make the way clear for his nomination as Commissioner of Internal Revenue or due to pressure. (4) The precedent took place at the height of the controversy which resulted in Senate institution of impeachment proceedings against President Johnson.

Going further afield, a few historical precedents can be found wherein, upon request, the President returned the resolution of confirmation to the Senate after the actual issuance of a commission. An outstanding example occurred in 1903. President Roosevelt had nominated William Plimley to be Assistant Treasurer of the United States at New York. ${ }^{27}$ The Senate had confirmed the nomination and notified the President of its action. A commission to Plimley had been duly signed, sealed and locked away in the vault of the Treasury Department. A letter to Plimley had been placed in the mails stating that he had been appointed and requesting him to enter bond as required by law. Thus under Marbury $v$. Madison the appointment was completed. All this had already transpired by the time the President received an unexpected Senate request for the return of the Plimley confirmation. Characteristically, President Roosevelt hesitated not a moment. He directed that all papers must be returned to the White House at once. As a result of this mandate, the letter directed to Plimley was extracted from the mails, the commission retrieved from the Treasury Department vault and returned to the White House. To clinch the matter, the President withdrew Plimley's nomination shortly afterward and substituted the name of another. ${ }^{28}$ Although with less drama, other executives of the United States have cooperated with the Senate to effect a last minute reversal of action in reference to an appointment. ${ }^{29}$ Patently, however, the

${ }^{27} 33$ id. Io, I7, 19, 46, 50, also records at executive offices of the White House and the Treasury Department.

${ }^{25} 33$ id. 46.

2 Beside the cases of Jeffrics and Plimley, described in the text, counsel for the Senate cffered sixteen cases as illustrations of this situation. Those cases were:

I. Pollock, Brigadier General by brevet (1867), I5 SEN. ExEC. J. 660, 681, 693, 696, 709; also Records of War Department.

2. Scott, Postmaster at Lowville, N. Y. (1876), i7 SEN. ExEc. J. 474, 479, 480, 482; also White House Records.

3. Bean, Ist lieutenant (1872), I8 SEN. Exec. J. I67, 178, 187, 273, 28r; also White House Records.

4. Legate, Governor of Washington Territory (1872), I8 SEN. ExEc. J. 182, 187, 192, 193, 229; also White House Records. 
few precedents of this type do not create or suggest a constitutional principle to assist in the solution of the suggested problem. Rather do they merely bring to light rare but invincible alliances between executive and legislative branches of the government resulting in effective removal of the officer in question.

On the other hand, no instance in the history of our government can be found wherein the President has refused to comply with a request for return of the notification when it affirmatively appears that the request was actually received before the issuance of a commission. The data compiled for the Smith case demonstrates that Presidents of the United States have consistently followed this practice from 1830 to date.

Yet this unvaried executive practice, these historical precedents above described, do not, at least in the writer's opinion, detract from or add materially to either side of the argument. The important fact remains that in the history of our federal government the question has not been squarely raised by the flat refusal of a President to accede to a Senate request for return upon the grounds that the confirmation and subsequent notification exhausted the Senate's power in the premises and transmitted sole control over the transaction to the executive branch of the Government charged, under the constitution, with the act of appointment.

We next turn to the legal precedents. Marbury v. Madison and United States v. LeBaron ${ }^{30}$ give no answer to the problem at hand. However they do define the issue clearly. They show that there are three separate

5. George Nourse, Register of Linkville Land Office, Oreg. (I872), I8 SEN. ExEc. J. 270, 274, 277, 312, 334-5; also White House Records.

6. Knight, U. S. Attorney for Northern Dist. of Florida (I878), I8 SEN. Exec. J. 378-9, 386, 389, 392-3; also White House Records.

7. Shannon, Chief Justice of Supreme Court of Dakota Territory (1873), I9 SEN. Exec. J. 73, 75, 79, 94, 96; also White House Records.

8. Shumard, Deputy Postmaster at Fort Smith, Ark. (I873), I8 SEN. ExEc. J. 387, 393, 404-5, 4I0; I9 id. I84; also White House Records.

9. Bliss, Deputy Postmaster at Columbus, Miss. (1873), ng SEN. Exec. J. 8I-2, 90, 100, I02; also White House Records.

I0. Clark, Deputy Postmaster at Montpelier, Vt. (I873), ig SEn. Exec J. 90, 9I, II4, 604, 75I; also White House Records.

I I. Tubbs, Postmaster at New London, Conn. (I878), 21 SEN. Exec. J. 442, 445, 449, 45I, 454-5; also White House Records.

I2. Durkee, Marshall for Northern District of Florida (1879), 22 SEN. Exec. J. 95, 96, 97, 98 ; also White House Records.

I3. Miles, Indian Agent at Osage Agency, Ind. T. (1883), 23 SEN. ExEc. J. 65Y-2, 667, 693 ; also White House Records.

14. Pritchard, U. S. Attorney for New Mexico (I883), 23 SEN. Exec. J. 653, 654, 657, 67I, 72I ; also White House Records.

I5. Reeves, Indian Agent Quapaw Agency, Ind. T. (I884), 24 SEr. Exec. J. 242, 243, 244, 2.15, 300; also White House Records.

16. Kursheedt, Marshall for Eastern District of La. (I889), 27 SEn. Exec. J. 15, 45, 46, 5I, 59, 6I, 7I; also White House Records.

All of these cases were cited by counsel for the Senate as instances wherein the records showed that the President had, upon request, returned resolutions of confirmation to the Senate after the issuance of commissions. Counsel for Smith challenged the accuracy of this assertion except in the cases of Jeffries, Legate, Shumard and Plimley. After study of the records, the writer is inclined to agree with the view taken on behalf of Smith.

${ }^{3}$ ig How. 73 (U. S. 1856). 
and distinct operations in the process of appointment. First, nomination by the President; second, confirmation by the Senate, third, the appointment by the President. Under these cases the signing of the commission is the last act required by law; the act which perfects the appointment; and the act which conveys title to the office to the appointee. Thus these decisions indicate that appointees derive title to office from Presidential appointment and not from Senatorial election in the form of confirmation. Thus the Senate's function in the premises is to give or withhold consent to the appointment so that the Executive charged with the appointive power can govern himself accordingly. To repeat, the action of the Senate does not convey title to office. Even if that body consents, the President is still under no obligation to appoint. ${ }^{31} \mathrm{He}$ is merely enabled to appoint if he so desires. Thus those cases are beside the point which hold that where a deliberative body is charged with the duty of making an appointment to public office, the vote of appointment is a completed executive act and not subject to reconsideration. ${ }^{32}$ Clearly, here the Senate is not a deliberative body charged with the duty of making appointments to public office. Clearly also the Senate has constitutional authority to "determine the rules of its proceedings". ${ }^{33}$ It has adopted a rule which permits reconsideration. Hence the question remains, does official notification to the President of Senate action truncate its power to reconsider during the entire period as defined by the rules?

There are no cases directly in point but dicta can be found in support of either answer to the question. For example, the following appears in Dust v. Oakman: ${ }^{34}$

"The question recurs whether, where an appointment or concurrence in an appointment is a subject of action by a deliberate body, that body may, by rules of its own, or acting under usual parliamentary rules, cast a vote upon the subject which is subject to reconsideration; for, if such course is permissible, the appointment is not complete beyond recall until the power to reconsider has been cut off by the lapse of time."

On the other hand, the court of last resort in New Jersey announces in Whitney v. VanBuskirk ${ }^{35}$ that:

"It is clear that while the matter of acceptance was under consideration by the Board of Councilmen, it was the right of that body

${ }^{3 x}$ Surprisingly enough, this point has actually been decided in California under a statute very similar in terminology to the applicable provisions of the United States Constitution. See Harrington v. Pardee, I Cal. App. 278, 82 Pac. 83 (I005).

${ }^{32}$ State v. Barbour, 53 Conn. 76, 22 Atl. 686 (I885); State v. Starr, 78 Conn. 636, 63 Atl. 512 (1906); State v. Phillips, 79 Me. 506, 10 Atl. 447 (I887); State v. Miller, 62 Ohio

St. 436,57 N. E. 227 (I900); State v. Tyrrell, I58 Wis. 425,149 N. W. 280 (I9r4).

${ }^{23}$ Unitted States Constitution, Art. I, Sec. 5, Clause 2.

${ }^{34} 126$ Mich. 717 at 721,86 N. W. 151 at 152 (I90r).

${ }^{3} 40$ N. J. L. 463 at $467(1878)$. 
to reconsider its vote, and vote as often as it saw fit upon the question, up to the time when, by a conclusive vote, accepted as such by itself, a determination was reached. Such final determination may be evinced by a public promulgation of the result, or by subsequent action inconsistent with the purpose of further review."

Each of these decisions represents a type of case perhaps useful in the discussion of this question, but each type presents a set of facts lacking some of the vital elements present in our problem. ${ }^{36}$ For example, the Dust v. Oakman type holds that a legislative body may reconsider its vote during the entire period permitted by its rules, and that assumption of office by an appointee before that time limit has expired, or before a motion to reconsider has been disposed of, will not perfect title to office in the appointee. ${ }^{37}$

Although the ruling announced by these cases seems at first important, that ruling must be examined in the light of the facts upon which it is based. Close analysis reveals that these cases can be distinguished in material respects. First they are cases of legislative election rather than executive appointment. The last act required by the body vested with the power of appointment has been done when confirmation, approval or consent is given. This stands in illuminating contrast to the situation under discussion, where the last act to perfect the appointment is up to the President and not to the Senate. Secondly, a most significant fact is missing in all the cases of the Dust $v$. Oakman variety. In each instance the legislative body vested with the approving power did not send forward notification to anyone that it had advised and consented to the nomination. By failing to give such notice it signified that it intended to keep the matter in its possession and control for consideration or reconsideration under its own rules. Hence, in the face of such circumstances, obviously the action of the appointees in assuming office could not transform a conditional approval into an unconditional consent.

The type of case represented by Whitney $v$. VanBuskirk stands for the proposition that no reconsideration of a vote may be had where the deliberative body has performed an act inconsistent with further review of the matter. ${ }^{38}$ But, although these cases possess the elements lacking in the Dust v. Oakman type, they must also be distinguished in that each legislative body in question seemed to have adopted no definite rules delimiting the

${ }^{23}$ No benefit would be gained by giving the exact facts of these cases here because the situations are complex, and the reporting of them often leaves much to the imagination. Furthermore, of course, they are state decisions and, therefore, of no great weight with reference to a question under the Constitution of the United States.

${ }^{7}$ See People ex rel. McMahon v. Davis, 284 I11. 439, I20 N. E. 326 (IgI8) ; Witherspoon v. State, 138 Miss. 310 , I03 So. 134 (I925); Crawford v. Gilchrist, 64 Fla. 4I, 59 So. 963 (1912): A more comprehensive list of cases will be found in Note appearing in ANNO; CAS. I9I4D at $304-307$.

In re Fitzgerald, 88 App. Div. 434, 82 N. Y. Supp. 8II (1903); State ex rel. Att'y Gen. v. Wadhams, 64 Minn. 318,67 N. W. 6.1 (1896). 
time for reconsideration. Hence in these cases the courts were confronted with the problem of deciding upon the particular facts presented whether or not final consent had been given to the appointment. The general test of finality seemed to be found in publication of or notification concerning confirmation. Although helpful, these decisions do not provide a satisfactory basis for a definite stand on our question because the Senate has adopted rules permitting reconsideration for a stated period.

Thus it is necessary to approach a practical consideration of the problem without the aid of much authority. It must be conceded that reconsideration confined within reasonable limits is valuable in preventing and correcting hastily made decisions. It must further be conceded that governmental emergencies do arise when quick decisions are necessary, when vacancies should be filled without delay. To combine both these essential features, an ideal reconsideration rule should, in the oidinary case, permit reconsideration of a vote for a sufficient period to ensure thoughtful judgment. It should, in the extraordinary case, permit immediate and final action. In general, this was the construction placed upon the present standing rules of the Senate in the Smith case.

It must also be admitted-as was admitted in the Smith case-that where two branches of the government are charged with concurrent functions, each must be kept informed concerning the action of the other. It is also plain common sense that such information should be conveyed in the form of an official notification. It must also be patent that the information conveyed should be of such character that it can be relied upon. Clearly, the notice itself would constitute no more than evidence of the action described in it. But, conceivably, some importance might be attached to the act of transmitting it. The George Otis Smith case ruled that when a special notice of Senate confirmation had been sent to the President, and the President has acted, the Senate is thereafter without power to pursue the matter.

Faced with this decision, either one of two possibilities persists. Either the transmission of the notice of consent to the President truncates the power of reconsideration, or the action of the President, in reliance on the notification, cuts off the Senate's power.

The writer can find no valid reason for the adoption of the second alternative. How can action of the executive make a revocable consent irrevocable and so affect the Senate's rights in the premises? The President can not appoint unless the Senate has consented. When the Senate has consented it has performed its constitutional function. The Constitution does not contemplate consent as the basis for presidential action unless that consent is final and unconditional. Even if constitutionally permissible, the idea that Senate consent is a warrant of attorney, valid until revolked, robs the transaction of the dignity which should be attached to the process 
of appointment. If such idea were adopted, the actual words of the official notice of consent from Senate to President would become meaningless and even misleading. Whereas the notice reads "the Senate advises and consents" it would in reality mean "we authorize you to proceed with the appointment unless we notify you to the contrary before you have acted." The executive would be forced to hurry the issuance of a commission in order to defeat the possibility of a change of heart upon the part of the Senate. Thus the practical working out of the idea to its logical conclusion does not tend to the orderly functioning of Government.

Jefferson's Manual of Parliamentary Procedure reads: ${ }^{39}$

"If, after the vote, the paper on which it has passed has been parted with, there can be no reconsideration: as if a vote has been for the passage of a bill, and the bill has been sent to the other House."

This passage suggests that the transmission of a paper upon which a vote has been taken to another body of the government charged with concurrent duties in respect thereto, is symbolical of the transit of control over the subject matter. The writer feels that when necessity arises this theory will be carried over into the case of presidential appointments-that the duly authorized act of official notification to the President will be held to be symbolic of the passage of control from the legislative to the executive branch of the Government-leaving the former without power to reverse its action unless control is restored to it by the voluntary action of the President.

If this view is taken the conclusion follows that the Senate does not itself have power to change its mind after notifying the President, that its consent becomes irrevocable upon the execution of its mandate of notification, and that the President can issue a valid commission in reliance upon official notification of Senate confirmation even where notice of recall reaches him before the appointment is perfected.

$\approx \S$ XLIII, par. 2. 